\title{
HOOKING MORTALITY OF YELLOW PERCH FROM EMMA LAKE, SASKATCHEWAN
}

DANA K. KELLETT, Box 88, Carrot River, SK SOE OLO

The primary purpose of fishing with a hook and line has changed over the years from a means of obtaining food to a form of recreation. ${ }^{9}$ Many management practises have incorporated the idea of "catch and release" fishing in areas of low population numbers or in areas of high fishing pressure so that a particular dish may be caught more than once. The Cheesman canyon, on the South Platte River, Colorado, was declared a "no-kill" area to protect the populations of rainbow Trout (Oncorhynchus mykiss) and Brown Trout (Salmo trutta). ${ }^{1}$ For most species there are daily and possession limits to protect population numbers. In addition, there are size restrictions to protect the most effective breeders in a system. For example, the current limit of walleye (Stizostedion vitreum) in Saskatchewan is five fish, with a possession limit of ten fish. ${ }^{8}$ Recently in Tobin Lake, Saskatchewan, a "no-keep" regulation for walleye ranging in size from $54-69 \mathrm{~cm}$ has been installed to protect the breeding population. ${ }^{4}$

These regulations require that many fish must be returned to the water after being caught. This led to concerns as to the fate of the released fish, as these regulations are only effective if the fish survive. A large number of assessments have been conducted in this area. However, most of the literature concentrates on salmonids ${ }^{2,3,10}$ and centrarchids. ${ }^{1,6,9}$ I found a few studies involving Walleye, ${ }^{5,7}$ a member of the perch family (Percidae), but I encountered none pertaining to Yellow Perch (Perca flavescens). The purpose of this study was to determine the percentage of "hooking mortality" that occurs in this species. It should be noted, however, that the results of this study will likely represent the low range of expected hooking mortality, as the experimental fish were artificially hooked by hand in a superficial location.

Methods This study was conducted at Emma Lake, Saskatchewan, in late August of 1994. Emma Lake is located near the south-east border of Prince Albert National Park, in the boreal forest - aspen parkland ecotone. During the course of this study, the mean water temperature was $20.0^{\circ} \mathrm{C}$ and the oxygen content was $8.5 \mathrm{ppm}$, and the shallow lake (maximum depth of $2.5 \mathrm{~m}$ ) was not stratified with respect to these parameters.

Two experiments were conducted. Mortality was assessed after 24 and 48 hours, in the first and second experiments, respectively. Fish were classified as dead or alive. Yellow perch were captured with a seine net and transferred to holding pens within 15 minutes of capture. Fish were recaught with dip nets from the holding pens and hooked artificially by hand three times with a single 
barbed hook. The location of hooking consisted of twice in the lower jaw or floor of the mouth and once in the upper jaw, resulting in some tissue tearing but very little or no bleeding in most cases. Fish were also 'dangled' by the hook for approximately three seconds to simulate being pulled from the water. Some fish were kept as a control, and were not subjected to hooking or additional handling. During the containment period, both groups were fed Gammarus spp., Hyallela spp., and other aquatic invertebrates twice daily, which were obtained from Emma Lake.

Results The 24-hour experiment involved 30 hooked and 25 control fish; no mortality was observed. The 48-hour experiment involved 25 hooked and 25 control fish. One individual in this experiment died, resulting in a mortality of $4.0 \%$. This was not statistically significant $\left(X^{2}=0.04\right.$, $d f=1, P>0.05$ ).

Discussion The low mortality observed in Yellow Perch indicates that fish hooked in a superficial location have a good chance of survival upon being released. There may be, however, some biases in this study, the primary one being with the method of hooking. Under natural conditions, fish will become hooked occasionally in more internal, vital areas, such as the tongue, gills, esophagus, and eye. This will lead to increased mortality. For example, Warner (1979) found that mortality occurred in $43.5 \%$ and $24.2 \%$ of Atlantic Salmon (Salmo salar) hooked in the gill/gill arch and esophagus regions, respectively.

This sharply contrasts with the lesser mortality observed when the salmon were hooked in superficial areas, such as the jaws and roof of the mouth ( $8.1 \%$ mortality), eye $(6.4 \%)$, and tongue/isthmus $(9.7 \%)$.
However, the results of this study are consistent with studies in which fish were hooked in superficial areas. ${ }^{3,6,10}$

Mortality may have been underestimated, as fish were only monitored for a maximum of 48 hours; their survival after this time is unknown. However, in a study involving cutthroat trout (Oncorhynchus clarki), Hunsaker et al. (1970) found that mortality was complete in 48 hours.

The control groups were important in ruling out other possible causes of mortality, if a higher percentage of mortality had occurred. Sources of stress may include that resulting from the seining and handling techniques, being held in a pen, and possible food deprivation. Because no mortality occurred in the control groups, these sources of stress did not significantly harm the fish in the short term.

This study could be improved by including a number of other variables, most obviously by using a natural method of hooking. Additionally, anatomical hooking site, $2,3,6$ gear type, ${ }^{2,5,9}$ and temperature ${ }^{2}$ are factors that have been found to influence hooking mortality of fish. This study is consistent with findings in earlier studies in the literature and reports on a species not previously examined in a more northern climate.

Acknowledgments This study was carried out as part of a requirement for an Honours Field Course (held at Emma Lake) of the Department of Biology, University of Saskatchewan. I would like to thank the Department of Biology, especially J.K. Schmutz, R.J.F. Smith, and S. Halpin. Appreciation is also due to R. Stinson and J. Bantle for help with the field work. 
1. ANDERSON, R.M. and R.B. NEHRING. 1984. Effects of a catch-andrelease regulation on a wild trout population in Colorado and its acceptance by anglers. North American Journal of Fisheries Management 4:257-265.

2. HUNSAKER, D.,II, L.F. MARNEKK and F.P. SHARPE. 1970. Hooking mortality of Yellowstone cutthroat trout. The Progressive Fish-Culturist 32:231-235.

3. LOFTUS, A.J., W.W. TAYLOR and M. KELLER. 1988. An evaluation of lake trout (Salvelinus namaucush) hooking mortality in the Upper Great Lakes. Canadian Journal of Fisheries and Aquatic Sciences 45:1473-1479.

4. NELSON, K. 1994. Limits protect top spawners in Tobin Lake. The Nipawin Journal 58(45):A1-A2.

5. PAYER, R.D., R.B. PIERCE and D.L. PEREIRA. 1989. Hooking mortality of walleyes caught on live and artificial baits. North American Journai of Fisheries Management 9:188-192.
6. PELZMAN, R.J. 1978. Hooking mortality of juvenile largemouth bass, Micropterus salmoides. California Fish and Game 64:185-188.

7. SCHAEFER, W.F. 1989. Hooking mortality of walleyes in a northwestern Ontario lake. North American Journal of Fisheries Management 9:193-194.

8. SASKATCHEWAN ENVIRONMENT AND RESOURCE MANAGEMENT. 1994. Saskatchewan Angling Guide 1994.

9. SIEWERT, H.F. and J.B. CAVE. 1990. Survival of released bluegill, Lepomis macrochirus, caught on artificial flies, worms, and spinner lures. Journal of Freshwater Ecology 5:407411.

10. WARNER, K. 1979. Mortality of landlocked Atlantic salmon hooked on four types of fishing gear at the hatchery. The Progressive Fish-Culturist 41:99102.
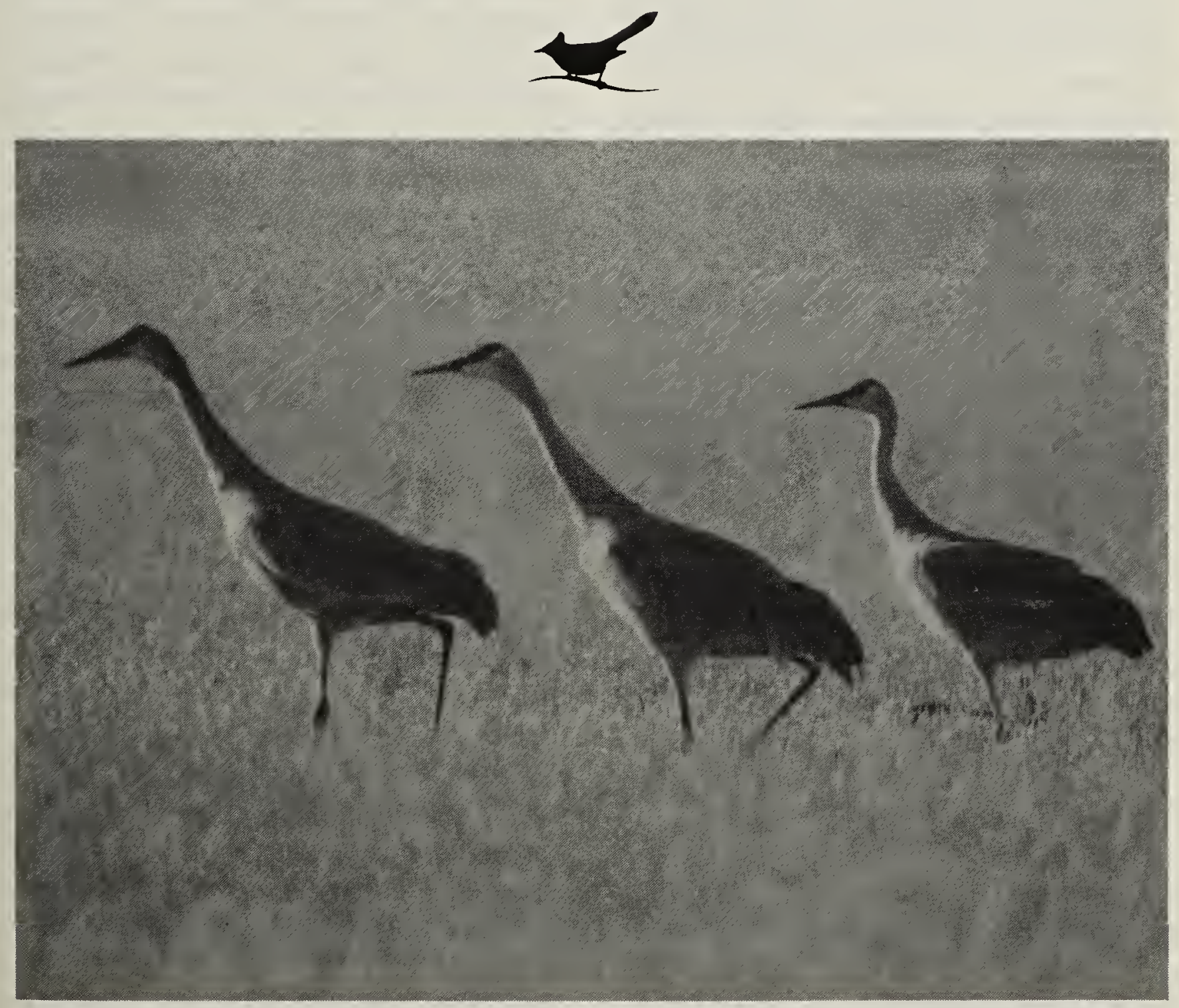